\title{
Outbreak of avian botulism and its effect on waterbirds in the Wilderness Lakes, South Africa
}

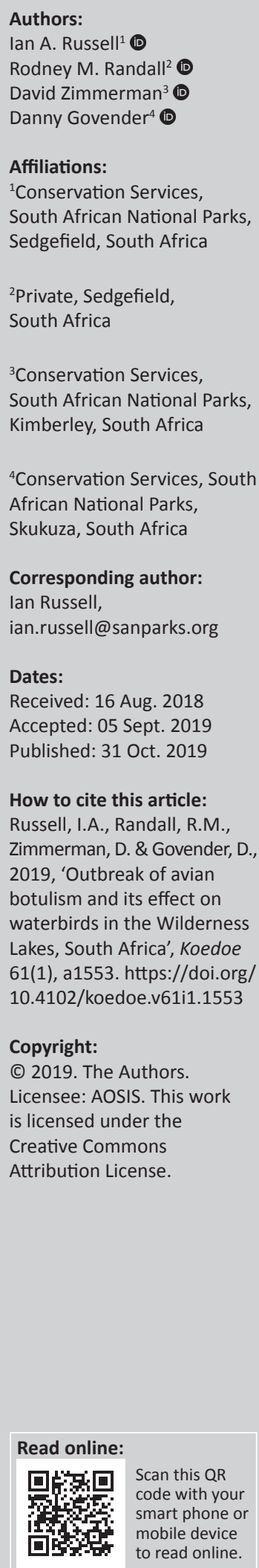

Avian botulism has been reported in many areas worldwide, particularly in North America, where at times it has resulted in die-offs of hundreds of thousands of waterbirds. By contrast, there are few reported cases in wild waterbird communities in South Africa. Mass die-offs of waterbirds in the Wilderness Lakes, South Africa, were first observed in January 2015, raising concerns about the effect of disease on the status of waterbird communities in this Ramsar site. Surveys of bird carcasses were undertaken between 2015 and 2017. An estimated 1115 individuals from 23 species were affected, with sick individuals displaying symptoms of avian type C, C and D or E botulism. The highest mortality was amongst red-knobbed coot (Fulica cristata), Cape shoveler (Anas smithii) and yellow-billed duck (Anas undulata), respectively comprising $60 \%, 18 \%$ and $9 \%$ of affected individuals. Cape shoveler was found to be particularly susceptible to the disease. Deaths occurred mainly during summer and autumn (November-April). No mortalities were recorded amongst 44 waterbird species, of which common moorhen (Gallinula choropus), African purple swamphen (Porphyrio madagascariensis) and reed cormorant (Phalacrocorax africanus) are widespread and abundant. The reasons for the outbreaks remain elusive, as environmental changes characteristic of a botulism outbreak, notably a decline in water level and dissolved oxygen, did not differ substantially from earlier years when no disease outbreaks were observed. The role of fish, and in particular the recently introduced common carp (Cyprinus carpio) in the progression of the disease, remains speculative, although worthy of investigation. The removal of carcasses for disease control should be continued.

Conservation implications: The long-term effect of repeated outbreaks of avian botulism on the abundance of susceptible waterbird species in the Wilderness Lakes is of concern. The previous regular high abundance of duck species, particularly yellow-billed duck and Cape shoveler, was the initial reason for the Wilderness Lakes being declared a Ramsar site. The effect of ongoing high disease-related mortalities may, in part, prevent these wetlands from continuing to regularly support globally significant populations of some waterbird species. The containment of the disease must be attempted by the regular collection and removal of dead birds and fish during the outbreak periods of November-June, and carcasses should be disposed of off-site. Further testing of affected individuals should be undertaken and the monitoring of environmental variables and affected individuals continued to improve the understanding of the drivers and progression of the disease.

Keywords: botulism; disease; wetlands; waterbirds; Ramsar; Wilderness Lakes.

\section{Introduction}

Avian botulism is a non-infectious bird disease resulting from the ingestion of toxins produced by the gram-positive bacterium Clostridium botulinum (Rocke \& Friend 1999). Seven different types of botulism neurotoxins occur, labelled A to G (Collins \& East 1998), as well as mosaics that have characteristics of two toxins (Rocke \& Friend 1999). Avian botulism outbreaks are typically caused by type C (Wobeser 1997), mosaic C/D (Anza et al. 2014) or type E (Getchell \& Bowser 2006; Rocke \& Friend 1999). Fish die-offs are typically caused by type E (Cromie et al. 2012). Clostridium botulinum is reportedly widespread in wetland sediments where outbreaks are common, and typically requires a source of protein, warm temperatures and low oxygen conditions to activate and produce toxin (Espelund \& Klaveness 2014). The salinity and $\mathrm{pH}$ of sediments and water may also affect the probability of botulism outbreaks in aquatic ecosystems (Rocke \& Friend 1999). The disease in birds is characterised by a flaccid paralysis of the muscles and is invariably fatal (Rocke \& Friend 1999). Death typically results from respiratory failure or drowning.

Avian botulism has been reported from several territories worldwide (Rocke 2006), including countries in both North America and South America (Rocke \& Friend 1999; Wobeser 1997), Europe 
(Włodarczyk et al. 2014; Woudstra et al. 2012), Africa (Blaker 1967), Australia (Grubb 1964) and New Zealand (Martinovich et al. 1972). Botulism is one of the most common causes of death in waterfowl in North America (Smith 1976; Wobeser 1997) where it has resulted in die-offs of hundreds of thousands of waterfowl in single events (Rocke \& Bollinger 2007). By contrast, there are only three published accounts comprising one peer-reviewed article (Blaker 1967) and two semi-popular articles (Ramollo 2016; Van Heerden 1972) of separate, smaller outbreaks in South Africa, suggesting that the disease is far less prevalent in Southern Africa than in North America and possibly Europe.

In this study, we document the repeated outbreak of disease affecting waterbirds and fish in the Wilderness Lakes, and discuss its relevance to the conservation of these aquatic ecosystems.

\section{Methods}

\section{Study area}

The Wilderness Lakes System $\left(33^{\circ} 59^{\prime}\right.$ to $34^{\circ} 02^{\prime} \mathrm{S}$ and $22^{\circ} 35^{\prime}$ to $22^{\circ} 46^{\prime} \mathrm{E}$ ) is located on the southern coastline of South Africa, and includes the Touw Estuary and three interconnected estuarine lakes (Rondevlei, Langvlei and Eilandvlei) (Figure 1). The Touw Estuary is a temporarily open-closed system, with closure of the estuary mouth dictated mostly by marine condition and river flow (Whitfield, Allanson \& Heinecken 1983). Under natural conditions, the breaching of the estuary would occur when the water level exceeds the height of the sandbar at the estuary mouth, which at times can attain $3.5 \mathrm{~m}$ above mean sea level (amsl). Natural breaching, however, seldom occurs with the estuary being artificially breached when water levels are between $2.1 \mathrm{~m}$ amsl and
$2.4 \mathrm{~m}$ amsl, in order to prevent the flooding of residential and other developed areas on the estuary floodplain (South African National Parks 2012). Fijen and Kapp (1995) estimated that under pristine conditions the estuary would have been open approximately $40 \%$ of the time. Open phases have, however, been reduced to an average of 30\% (1991-2017) (SANParks unpublished data) as a result of both artificial breaching and freshwater deprivation. Estuary breaching and closure results in substantial variability in water levels and physico-chemical properties in the lakes.

Rainfall occurs year-round, with a mean of between $900 \mathrm{~mm}$ / year and $1000 \mathrm{~mm} /$ year in the upper catchments (Adamson 1975). One perennial and two intermittently flowing rivers provide surface freshwater flow to the lake system. The lower catchment of the larger (catchment $\sim 89.1 \mathrm{~km}^{2}$ ) perennial Touw River and the majority of the catchments of the smaller, intermittently flowing Duiwe River $\left(\sim 32.5 \mathrm{~km}^{2}\right)$ and Langvlei Spruit $\left(\sim 17.8 \mathrm{~km}^{2}\right)$ support intensive, mostly livestock-based agricultural practices (Filmalter \& O'Keeffe 1997). River water has a high humic matter content, is low in electrolytes (Robarts \& Allanson 1977) and is acidic (median pH in Touw River $=5.1$, Duiwe River $=6.7$ in 1991-2014 [SANParks unpublished data]).

Submerged aquatic plants are widespread and abundant in the shallower $(<3 \mathrm{~m})$ littoral areas of the lakes. Dominant taxa are fennel-leaved pondweed (Potamogeton pectinatus), water hornwart (Ceratophyllum demersum), stoneworts (Charophyta) and filamentous algae (Howard-Williams \& Liptrot 1980; Weisser \& Howard-Williams 1982; Whitfield et al. 1983). Stands of emergent aquatic plants occur on the lake margins and floodplains, with abundant species including common reed (Phragmites australis), clubrush (Schoenoplectus scirpoides)

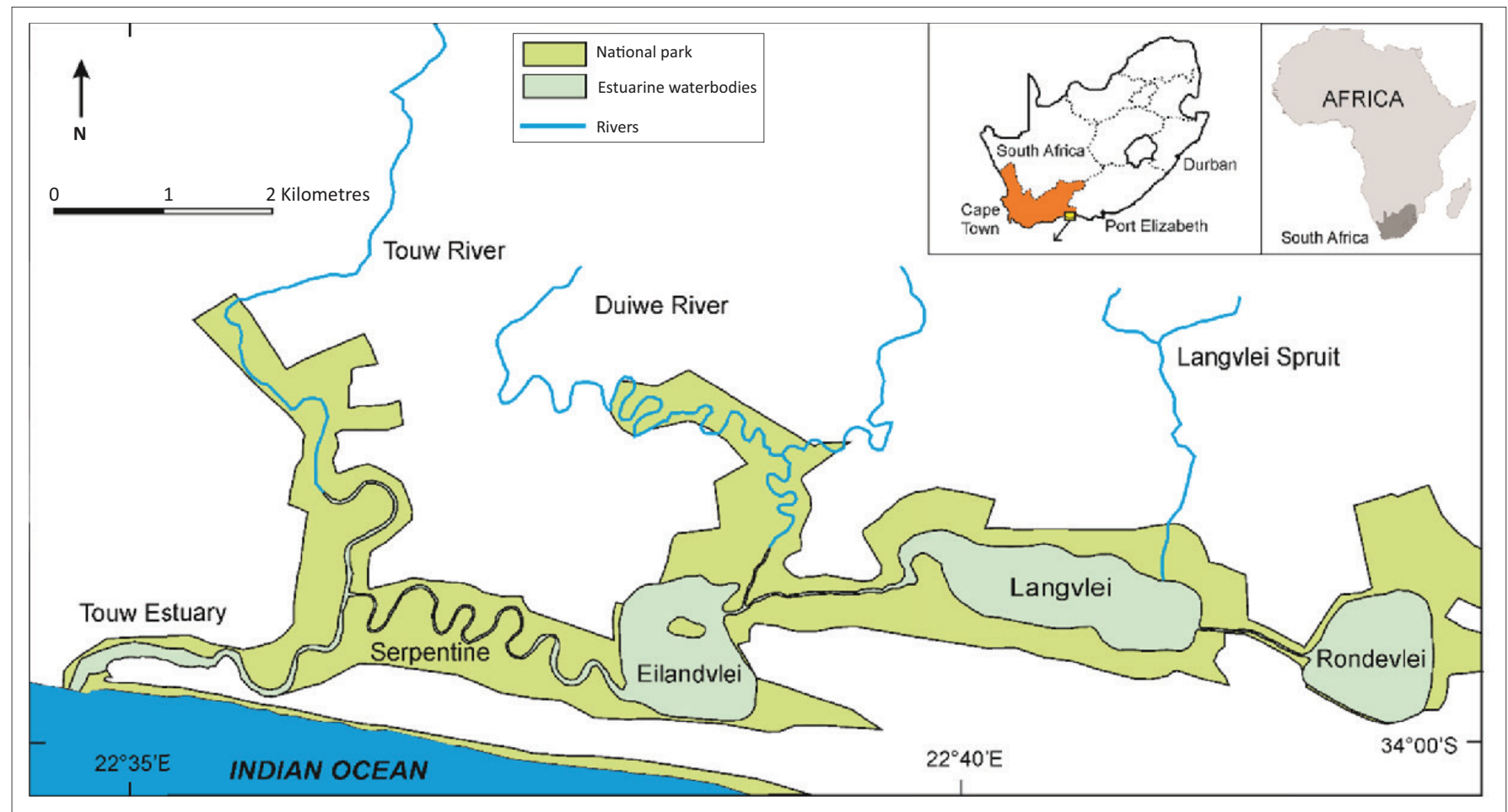

FIGURE 1: Map of study area showing relative position of estuarine lakes within the Wilderness Lakes Complex. 
and bullrush (Typha capensis). The fish community consists of estuarine, euryhaline marine and freshwater alien species (Hall, Whitfield \& Allanson 1987; Olds et al. 2011; Russell 1996; Whitfield 1984). The lakes, and in particular Langvlei and Rondevlei, support abundant and diverse waterbird communities (Boshoff, Palmer \& Piper 1991a, 1991b, 1991c; Russell, Randall \& Hanekom 2014).

The Wilderness Lakes System is located in the Garden Route National Park. The lakes and their interleading channels were designated as a wetland of international importance, or Ramsar site, in 1991 (Ramsar Convention Bureau 2019).

\section{Abundance of living and dead waterbirds}

Surveys of the abundance of all waterbirds were undertaken biannually during summer (January-February) and winter (July-August) from 2005 to 2017. Surveys were undertaken from a boat over two days by four observers using binoculars. The boat route used enabled the observation of all open water areas and exposed sandbanks and mudflats.

The first bird carcasses were observed and reported by members of the public in January 2015 in front of a bird hide on the northern shoreline of Rondevlei. Shortly thereafter, during regular boat-based surveys on the lakes by South African National Parks (SANParks) personnel to assess aspects of water quality and waterbird abundance, the scale and extent of the outbreak became more apparent, with the observation of multiple bird and fish carcasses on Eilandvlei, Langvlei and Rondevlei.

To monitor the carcass occurrence, regular boat-based surveys were undertaken of all the waterbodies between January 2015 and May 2017, following routes that enabled observation of all the open water areas. Twenty surveys were conducted on Eilandvlei over a period of 256 days, 37 on Langvlei over 462 days and 56 on Rondevlei over 528 days. These equate to surveys being conducted, on average, once every 13, 12 and 9 days respectively, although, during the height of the outbreak, surveys were conducted at shorter intervals. Intermittent surveys were undertaken on the Touw Estuary and adjacent Swartvlei system. All observed and accessible bird and fish carcasses were collected and, where possible, identified. Live birds (approximately 30) with paralysis and those that were unable to walk or fly were captured and identified. Those in an advanced state of paralysis and in the process of drowning when captured were euthanised. All collected dead and sick birds, and all dead fish, were removed from the lakes. All carcasses not used for laboratory analyses were disposed of by burying at a site removed from the lakes in an attempt to try and contain the disease.

\section{Disease identification in waterbirds}

State veterinarians were consulted to provide guidance on the probable cause of the bird deaths. Three dead and one paralysed yellow-billed duck (Anas undulata) were collected in early March 2015. A full post-mortem was conducted, including a histopathological examination of the lung, liver, intestine, pancreas, proventriculus and brain tissues. Organ swabs were tested by means of polymerase chain reaction (PCR) for avian influenza and Newcastle disease. Bacterial cultures were undertaken of organ fluids.

Four frozen whole carcasses of affected and euthanased waterbirds comprising two Cape shoveler (Anas smithii), one red-knobbed coot (Fulica cristata) and one blacksmith lapwing (Vanellus armatus), collected in March 2015, and two water samples from Rondevlei and Langvlei were submitted to the Agricultural Research CouncilOnderstepoort Veterinary Institute (Pretoria) by SANParks. Mouse bioassays for the toxin of $C$. botulinum were conducted on samples of both water and waterbird intestinal contents. Post-mortem and histopathological examinations of heart, small intestine, gizzard, pancreas, aorta, liver, trachea, proventriculus, kidneys, lungs, cerebrum, cerebellum and testes were conducted. Bacterial cultures were undertaken of pooled liver swabs.

Tissue samples of major organs and muscles of three diseaseaffected and euthanased waterbirds, namely, one each of yellow-billed duck, great crested grebe (Podiceps cristatus) and southern pochard (Netta erythrophthalma), and one recently dead adult fish, a white steenbras (Lithognathus lithognathus), were harvested by SANParks Veterinary Wildlife Services on 14 December 2015. All tissue samples were preserved in $10 \%$ formalin and submitted to the Wildlife Pathology Research of the National Zoological Gardens (Pretoria) for histopathological examination.

\section{Presence of toxic algae and diatoms}

Water samples were collected in polypropylene bottles from nine localities $(2 \times$ Rondevlei, $2 \times$ Rondevlei-Langvlei channel, $1 \times$ Langvlei, $1 \times$ Langvlei-Eilandvlei channel, $2 \times$ Eilandvlei, $1 \times$ Serpentine channel) on 20 February 2015, during the height of the first disease outbreak. Sample preparations and species identifications were undertaken by the Stellenbosch Office of the Council for Scientific and Industrial Research (CSIR). All water column algae were identified using a compound microscope (Carl Zeis, Germany) at $1250 \times$ magnification and keys of Truter (1987), Wehr and Sheath (2003), Van Vuuren et al. (2006) and Taylor, Harding and Archibald (2007). Diatom samples were heated in a sulphuric acid and potassium dichromate solution to clear them of organic matter and thereafter rinsed, diluted and mounted in a Pleurax medium for microscopic examination. Samples were sedimented in an algae chamber and evaluated using the strip-count method (American Public Health Association, American Water Works Association \& Water Pollution Control Federation 1992).

\section{Environmental parameters prior to and during the disease outbreak}

Water level data for the lakes were extracted from the unpublished databases of the South African Department of Water and Sanitation. Temperature $\left({ }^{\circ} \mathrm{C}\right)$, salinity, dissolved 
oxygen $(\mathrm{mg} / \mathrm{l})$ and $\mathrm{pH}$ of lake waters were measured quarterly by SANParks personnel at $30 \mathrm{~cm}$ depth at five localities in each lake using YSI model $30 \mathrm{~S}-\mathrm{C}-\mathrm{T}$, model 550A $\mathrm{O}_{2}$ and model $60 \mathrm{pH}$ meters.

The standing biomass of submerged plants was determined during May and June from 1992 to 2017. In Rondevlei and Langvlei, assessments between 2000 and 2004 were undertaken biennially. Four littoral transects extending from the inner edge of the emergent macrophyte zone to the $2 \mathrm{~m}$ depth contour were randomly positioned around each lake each year. The above-ground portions of aquatic plants were collected at five $0.0625 \mathrm{~m}^{2}$ sample points along each transect with a submerged macrophyte sampler (Howard-Williams \& Longman 1976). Living plant tissue was oven-dried at $55^{\circ} \mathrm{C}$ for approximately 1 week and thereafter weighed on an electronic balance (Sartorius) to the nearest gram.

\section{Ethical considerations}

This article followed all ethical standards for research without direct contact with human or animal subjects.

\section{Results}

\section{Waterbirds affected}

A total of 1115 dead or disease-affected waterbirds were recorded on Rondevlei, Langvlei and Eilandvlei between
January 2015 and May 2017. This constituted 20\% of the number of individuals that, on average, occur on these waterbodies. Twenty-three species from 13 families were affected (Table 1), with the highest mortality being amongst red-knobbed coot (670 individuals), Cape shoveler (204) and yellow-billed duck (100), respectively comprising 60\%, 18\% and $9 \%$ of affected individuals.

There is a strong similarity for most species between the percentage of individuals affected per species and the percentage representation in the waterbird community (Table 1). This is particularly apparent in two of the three most affected species, namely red-knobbed coot and yellow-billed duck, where the percentages of community representation and disease-affected individuals are identical. By contrast, Cape shoveler appeared to be particularly susceptible to the disease, with the percentage of individuals affected (18\%) far exceeding community representation $(4 \%)$. The number of dead and dying Cape shoveler (204 individuals), a regularly occurring species on the lakes, is a substantial portion (78\%) of the average population (261 individuals). Although the number of dead greater flamingo (Phoenicopterus ruber) (12 individuals) exceed the average population size (six individuals), this does not necessarily suggest above average susceptibility to the disease, as this species is an intermittent, mostly winter migrant to the Wilderness Lakes, and abundances can vary substantially from year to year. Greater flamingo

TABLE 1: Population statistics and number of mortalities of waterbird species affected by botulism.

\begin{tabular}{|c|c|c|c|c|c|c|c|}
\hline \multirow[t]{2}{*}{ Family } & \multirow[t]{2}{*}{ Species } & \multirow[t]{2}{*}{ Common name } & \multicolumn{3}{|c|}{$\begin{array}{l}\text { Waterbird communities } \\
(2005-2014)\end{array}$} & \multicolumn{2}{|c|}{$\begin{array}{c}\text { Mortalities } \\
(2015-2017)\end{array}$} \\
\hline & & & Freq. & Avg. & $\%$ & No. & $\%$ \\
\hline \multirow[t]{2}{*}{ Dendrocygnidae } & Dendrocygna bicolor & Fulvous duck & 5 & $<1$ & $<1$ & 1 & $<1$ \\
\hline & Thalassornis leuconotus & White-backed duck & 100 & 74 & 1 & 6 & 1 \\
\hline \multirow[t]{6}{*}{ Anatidae } & Anas smithii & Cape shoveler & 100 & 261 & 4 & 204 & 18 \\
\hline & Anas undulata & Yellow-billed duck & 100 & 544 & 9 & 100 & 9 \\
\hline & Anas erythrorhyncha & Red-billed teal & 90 & 56 & 1 & 5 & $<1$ \\
\hline & Oxyura maccoa & Maccoa duck & 85 & 19 & $<1$ & 4 & $<1$ \\
\hline & Netta erythropthalma & Southern pochard & 100 & 126 & 2 & 4 & $<1$ \\
\hline & Alopochen aegyptiacus & Egyptian goose & 100 & 153 & 3 & 24 & 2 \\
\hline Cerylidae & Ceryle rudis & Pied kingfisher & 95 & 3 & $<1$ & 1 & $<1$ \\
\hline Rallidae & Fulica cristata & Red-knobbed coot & 100 & 3597 & 60 & 670 & 60 \\
\hline Charadriidae & Vanellus armatus & Blacksmith lapwing & 100 & 26 & $<1$ & 1 & $<1$ \\
\hline Laridae & Larus cirrocephalus & Grey-headed gull & 45 & 3 & $<1$ & 1 & $<1$ \\
\hline Accipitridae & Haliaeetus vocifer & African fish-eagle & 100 & 6 & $<1$ & 1 & $<1$ \\
\hline \multirow[t]{2}{*}{ Recurvirostridae } & Recurvirostra avosetta & Pied avocet & 25 & 3 & $<1$ & 1 & $<1$ \\
\hline & Himantopus himantopus & Black-winged stilt & 95 & 33 & 1 & 4 & $<1$ \\
\hline \multirow[t]{2}{*}{ Podicipedidae } & Tachybaptus ruficollis & Little grebe & 100 & 269 & 5 & 7 & 1 \\
\hline & Podiceps cristatus & Great crested grebe & 100 & 209 & 4 & 11 & 1 \\
\hline Phalacrocoracidae & Phalacrocorax lucidus & White-breasted cormorant & 100 & 59 & 1 & 8 & 1 \\
\hline \multirow[t]{2}{*}{ Ardeidae } & Ardeola ralloides & Squacco heron & 10 & $<1$ & $<1$ & 2 & $<1$ \\
\hline & Egretta garzetta & Little egret & 95 & 31 & 1 & 2 & $<1$ \\
\hline Phoenicopteridae & Phoenicopterus ruber & Greater flamingo & 15 & 6 & $<1$ & 12 & 1 \\
\hline \multirow[t]{3}{*}{ Threskiornithidae } & Platalea alba & African spoonbill & 90 & 21 & $<1$ & 4 & $<1$ \\
\hline & Plegadis falcinellus & Glossy ibis & 95 & 14 & $<1$ & 1 & $<1$ \\
\hline & Not identified & - & - & - & - & 41 & 4 \\
\hline Total & - & - & - & 5512 & - & 1115 & - \\
\hline
\end{tabular}

Note: For waterbird communities surveyed biannually in Rondevlei, Langvlei and Eilandvlei over 10 years (2005-2014) prior to the initial outbreak of botulism. Species names follow Hockey et al. (2005). Freq. indicates the percentage of times a species was recorded in all surveys; Avg. is the average abundance of species across all 20 surveys; and \% is the percentage representation of a species in the community based on average abundance across all 20 surveys. For statistics of waterbird mortalities recorded in the 3-year study period (2015-2017) in Rondevlei, Langvlei and Eilandvlei, No. indicates the number of sick and dead individuals of each waterbird species located in botulism-affected waterbodies; and \% indicates percentage representation of a species in the total number of affected individuals recorded in all affected waterbodies.

Freq., frequent; Avg., average. 
were a typical abundant in 2016, with arrivals in late summer, and 453 individuals were counted in the winter 2016 surveys. Relatively abundant species that were affected by the disease, but where the percentage of affected individuals was notably lower than community representation, included both little grebe (Tachybaptus ruficollis) and great crested grebe (Table 1).

The highest number of waterbird deaths over the 3-year study period occurred on Rondevlei (570), followed by Langvlei (473) and Eilandvlei (72) (Table 2). No affected waterbirds were observed on either the Touw Estuary or the adjacent Swartvlei system. The highest mortality occurred on Langvlei in 2015 and on Rondevlei in 2016. Mortalities were recorded only on Langvlei in 2017 (Table 2).

There was temporal variability in the disease outbreak, with the majority (95\%) of waterbird deaths occurring in the summer and autumn months of November-April, with no deaths recorded in the late winter months of September and October (Figure 2a).

No mortalities were recorded amongst 44 additional waterbird species (Table 3), of which common moorhen (Gallinula choropus), African purple swamphen (Porphyrio madagascariensis) and reed cormorant (Phalacrocorax africanus) are widespread and abundant.

\section{Symptoms seen in clinically affected birds}

Most affected birds were found in areas of dense flooded plants, or on the shoreline, and were frequently grouped in one or more localities on a waterbody. Birds that were on the shoreline, or propped up by emergent plants, were generally hunched over and unable to stand. All affected individuals were either reluctant or unable to fly, and when attempting to do so were only able to propel themselves for very short distances across the water surface or mudflats with their wings. Most displayed paralysis of the neck and were unable to hold up their head. This was particularly prevalent in the longer-necked species such as ducks and cormorants, many of which, when located, were struggling to hold their head above water. When on land, none were able to stand, and when attempting to walk exhibited a floppy stumbling gate for very short distances. Most were unable to walk, and either sat hunched over or lay laterally recumbent with their legs and necks stretched out. In extreme cases, individuals seemed completely paralysed and unresponsive. Most had their eyes either partially or fully closed.

\section{Fishes affected}

A total of 124 dead fish from eight species were observed in the Wilderness Lakes over the same period when the waterbird deaths occurred. All dead fish, with the exception of one Cape stumpnose (Rhabdosargus holubi) and one oval

TABLE 2: The number of disease-affected waterbirds located in Rondevlei, Langvlei and Eilandvlei in the three different botulism outbreak periods encompassing January-June 2015, November 2015 - August 2016 and January-May 2017.

\begin{tabular}{|c|c|c|c|c|c|c|c|c|c|c|c|c|c|c|}
\hline \multirow[t]{2}{*}{ Family } & \multirow[t]{2}{*}{ Species } & \multirow[t]{2}{*}{ Common name } & \multicolumn{4}{|c|}{ Rondevlei } & \multicolumn{4}{|c|}{ Langvlei } & \multicolumn{4}{|c|}{ Eilandvlei } \\
\hline & & & 2015 & 2016 & 2017 & Total & 2015 & 2016 & 2017 & Total & 2015 & 2016 & 2017 & Total \\
\hline \multirow[t]{2}{*}{ Dendrocygnidae } & Dendrocygna bicolor & Fulvous duck & 0 & 0 & 0 & 0 & 1 & 0 & 0 & 1 & 0 & 0 & 0 & 0 \\
\hline & Thalassornis leuconotus & White-backed duck & 1 & 0 & 0 & 1 & 5 & 0 & 0 & 5 & 0 & 0 & 0 & 0 \\
\hline \multirow[t]{6}{*}{ Anatidae } & Anas smithii & Cape shoveler & 8 & 46 & 0 & 54 & 69 & 64 & 10 & 143 & 7 & 0 & 0 & 7 \\
\hline & Anas undulata & Yellow-billed duck & 28 & 9 & 0 & 37 & 51 & 1 & 0 & 52 & 11 & 0 & 0 & 11 \\
\hline & Anas erythrorhyncha & Red-billed teal & 1 & 2 & 0 & 3 & 2 & 0 & 0 & 2 & 0 & 0 & 0 & 0 \\
\hline & Oxyura maccoa & Maccoa duck & 0 & 2 & 0 & 2 & 2 & 0 & 0 & 2 & 0 & 0 & 0 & 0 \\
\hline & Netta erythropthalma & Southern pochard & 1 & 3 & 0 & 4 & 0 & 0 & 0 & 0 & 0 & 0 & 0 & 0 \\
\hline & Alopochen aegyptiacus & Egyptian goose & 1 & 3 & 0 & 4 & 15 & 3 & 1 & 19 & 1 & 0 & 0 & 1 \\
\hline Cerylidae & Ceryle rudis & Pied kingfisher & 0 & 0 & 0 & 0 & 0 & 1 & 0 & 1 & 0 & 0 & 0 & 0 \\
\hline Rallidae & Fulica cristata & Red-knobbed coot & 44 & 385 & 0 & 429 & 149 & 37 & 10 & 196 & 39 & 6 & 0 & 45 \\
\hline Charadriidae & Vanellus armatus & Blacksmith lapwing & 0 & 0 & 0 & 0 & 0 & 1 & 0 & 1 & 0 & 0 & 0 & 0 \\
\hline Laridae & Larus cirrocephalus & Grey-headed gull & 0 & 0 & 0 & 0 & 1 & 0 & 0 & 1 & 0 & 0 & 0 & 0 \\
\hline Accipitridae & Haliaeetus vocifer & African fish-eagle & 1 & 0 & 0 & 1 & 0 & 0 & 0 & 0 & 0 & 0 & 0 & 0 \\
\hline \multirow[t]{2}{*}{ Recurvirostridae } & Recurvirostra avosetta & Pied avocet & 0 & 1 & 0 & 1 & 0 & 0 & 0 & 0 & 0 & 0 & 0 & 0 \\
\hline & Himantopus himantopus & Black-winged stilt & 0 & 2 & 0 & 2 & 2 & 0 & 0 & 2 & 0 & 0 & 0 & 0 \\
\hline \multirow[t]{2}{*}{ Podicipedidae } & Tachybaptus ruficollis & Little grebe & 0 & 4 & 0 & 4 & 1 & 0 & 1 & 2 & 1 & 0 & 0 & 1 \\
\hline & Podiceps cristatus & Great crested grebe & 3 & 0 & 0 & 3 & 4 & 3 & 0 & 7 & 1 & 0 & 0 & 1 \\
\hline Phalacrocoracidae & Phalacrocorax lucidus & White-breasted cormorant & 2 & 0 & 0 & 2 & 2 & 1 & 0 & 3 & 3 & 0 & 0 & 3 \\
\hline \multirow[t]{2}{*}{ Ardeidae } & Ardeola ralloides & Squacco heron & 0 & 0 & 0 & 0 & 2 & 0 & 0 & 2 & 0 & 0 & 0 & 0 \\
\hline & Egretta garzetta & Little egret & 0 & 1 & 0 & 1 & 0 & 1 & 0 & 1 & 0 & 0 & 0 & 0 \\
\hline Phoenicopteridae & Phoenicopterus ruber & Greater flamingo & 0 & 10 & 0 & 10 & 0 & 0 & 1 & 1 & 0 & 1 & 0 & 1 \\
\hline \multirow[t]{3}{*}{ Threskiornithidae } & Platalea alba & African spoonbill & 0 & 2 & 0 & 2 & 2 & 0 & 0 & 2 & 0 & 0 & 0 & 0 \\
\hline & Plegadis falcinellus & Glossy ibis & 1 & 0 & 0 & 1 & 0 & 0 & 0 & 0 & 0 & 0 & 0 & 0 \\
\hline & Not identified & - & 9 & 0 & 0 & 9 & 30 & 0 & 0 & 30 & 2 & 0 & 0 & 2 \\
\hline Total & - & - & 99 & 470 & 0 & 570 & 338 & 112 & 23 & 473 & 65 & 7 & 0 & 72 \\
\hline
\end{tabular}

Note: Species names follow Hockey et al. (2005).

Survey dates for the three locations were as follows: Rondevlei 2015: January-June 2015, Rondevlei 2016: November 2015 - August 2016 and Rondevlei 2017 : January-May 2017; Langvlei 2015: February-June 2015, Langvlei 2016: November 2015 - June 2016 and Langvlei 2017: January-May 2017; and Eilandvlei 2015: February-May 2015, Eilandvlei 2016: January-June 2016 and Eilandvlei 2017: January-May 2017 


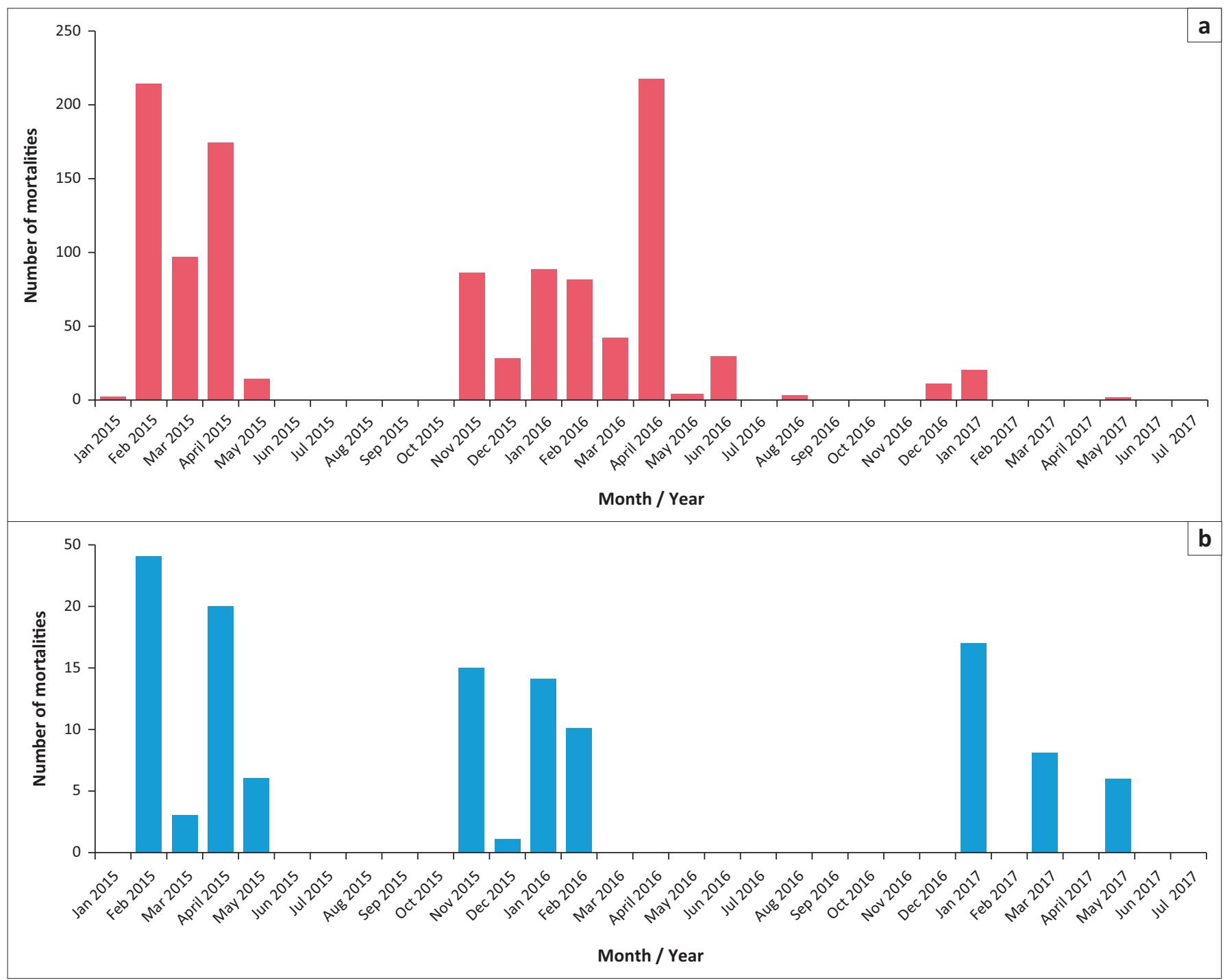

FIGURE 2: Number of (a) waterbird and (b) fish mortalities recorded in the Wilderness Lakes per month between January 2015 and July 2017.

moonie (Monodactylus falciformis), were large $(>30 \mathrm{~cm}$ total length). Common carp (Cyprinus carpio) was the most abundant species of dead fish in both Eilandvlei (48\%) and Langvlei (84\%), as well as collectively across all waterbodies $(72 \%)$ (Table 4). Observed fish mortality was highest in Langvlei (72\%) and comparatively uncommon in Rondevlei (5\%) (Table 4). Temporal variability in fish deaths coincided with that of waterbirds, with dead individuals observed from November to May (Figure 2b).

\section{Post-mortal findings}

Laboratory assessments undertaken by state veterinarians on four yellow-billed duck indicated minimal to severe autolysis. All of the birds' gastrointestinal tracts were empty. PCR tests were negative for both Newcastle disease and avian influenza. No significant bacteria isolates were cultured from body fluids. A histological assessment of lung, liver, intestine, pancreas and brain tissue did not indicate any diagnostic significant microscopic lesions. Oedema intermingled with large numbers of bacteria and non-cellular debris within the parabronchi, most probably from aspirated water, was indicative of drowning. Similarly, a post-mortem and histopathological examination of carcasses submitted to the ARC-Onderstepoort Veterinary Institute and Wildlife Pathology Research revealed no specific lesions that could be associated with mass waterbird deaths. Water and intestinal samples were negative on the mouse bioassay for C. botulinum toxins. These samples were also negative on anaerobic culture for Clostridium species or any other significant bacteria species. Based on the negative histopathology and laboratory results and clinical symptoms of affected birds, a presumptive diagnosis of avian botulism was made.

The single fish examined histologically, a white steenbras, only revealed epithelial hyperplasia of the gills, indicating subacute bronchitis, possibly because of altered environmental conditions, with death likely as a result of respiratory failure.

\section{Environmental conditions during disease outbreak}

All of the waterbodies are interconnected; as a result, variability in their water levels is similar. Within the lake system, this variability is depicted by data from Rondevlei (Figure 3). Breaching of the Touw Estuary, both natural and 
TABLE 3: Population statistics of waterbird species not affected by botulism. For waterbird communities surveyed biannually in Rondevlei, Langvlei and Eilandvlei over 10 years (2005-2014) prior to the initial outbreak of botulism.

\begin{tabular}{|c|c|c|c|c|c|}
\hline \multirow[t]{2}{*}{ Family } & \multirow[t]{2}{*}{ Species } & \multirow[t]{2}{*}{ Common name } & \multicolumn{3}{|c|}{$\begin{array}{l}\text { Waterbird communities } \\
\quad(2005-2014)\end{array}$} \\
\hline & & & Freq. & Avg. & $\%$ \\
\hline \multirow[t]{4}{*}{ Anatidae } & Tadorna cana & African shell-duck & 5 & $<1$ & $<1$ \\
\hline & Anas capensis & Cape teal & 65 & 4 & $<1$ \\
\hline & Anas hottentota & Hottentot teal & 70 & 6 & $<1$ \\
\hline & Plectropterus gambensis & Spur-winged goose & 70 & 7 & $<1$ \\
\hline \multirow[t]{2}{*}{ Alcedinidae } & Alcedo semitorquata & Half-collared kingfisher & 10 & $<1$ & $<1$ \\
\hline & Alcedo cristata & Malachite kingfisher & 100 & 8 & $<1$ \\
\hline Cerylidae & Megaceryle maximus & Giant kingfisher & 10 & $<1$ & $<1$ \\
\hline \multirow[t]{4}{*}{ Rallidae } & Rallus caerulescens & African rail & 35 & $<1$ & $<1$ \\
\hline & Amaurornis flavirostris & Black crake & 90 & 3 & $<1$ \\
\hline & Porphyrio madagascariensis & African purple swamphen & 100 & 13 & $<1$ \\
\hline & Gallinula choropus & Common moorhen & 100 & 52 & 1 \\
\hline \multirow[t]{7}{*}{ Scolopacidae } & Tringa glareola & Wood sandpiper & 40 & 1 & $<1$ \\
\hline & Tringa stagnatilis & Marsh sandpiper & 30 & 2 & $<1$ \\
\hline & Tringa nebularia & Common greenshank & 40 & 3 & $<1$ \\
\hline & Calidris ferruginea & Curlew sandpiper & 10 & 2 & $<1$ \\
\hline & Calidris minuta & Little stint & 15 & 4 & $<1$ \\
\hline & Philomachus pugnax & Ruff & 60 & 19 & $<1$ \\
\hline & Gallinago nigripennis & Ethiopian snipe & 45 & 2 & $<1$ \\
\hline Jacanidae & Actophilornis africanus & African jacana & 30 & 1 & $<1$ \\
\hline Burhinidae & Burhinus vermiculatus & Water thick-knee & 35 & 1 & $<1$ \\
\hline \multirow[t]{3}{*}{ Charadriidae } & Charadrius haiticula & Ringed plover & 20 & 1 & $<1$ \\
\hline & Charadrius pecuarius & Kittlitz's plover & 75 & 8 & $<1$ \\
\hline & Charadrius tricollaris & Three-banded plover & 70 & 4 & $<1$ \\
\hline \multirow[t]{4}{*}{ Laridae } & Larus dominicanus & Kelp gull & 100 & 8 & $<1$ \\
\hline & Sterna caspia & Caspian tern & 40 & 1 & $<1$ \\
\hline & Sterna hirundo & Common tern & 60 & 7 & $<1$ \\
\hline & Chlidonias hybrida & Wiskered tern & 25 & 1 & $<1$ \\
\hline \multirow[t]{2}{*}{ Accipitridae } & Circus ranivorus & African marsh-harrier & 100 & 4 & $<1$ \\
\hline & Pandion haliaetus & Osprey & 30 & $<1$ & $<1$ \\
\hline Podicipedidae & Podiceps nigricollis & Black-necked grebe & 60 & 24 & $<1$ \\
\hline Anhingidae & Anhinga rufa & African darter & 95 & 15 & $<1$ \\
\hline \multirow[t]{2}{*}{ Phalacrocoracidae } & Phalacrocorax capensis & Cape cormorant & 65 & 45 & 1 \\
\hline & Phalacrocorax africanus & Reed cormorant & 100 & 177 & 3 \\
\hline \multirow[t]{7}{*}{ Ardeidae } & Ardea cinerea & Grey heron & 95 & 6 & $<1$ \\
\hline & Ardea melanocephala & Black-headed heron & 70 & 1 & $<1$ \\
\hline & Ardea purpurea & Purple heron & 100 & 9 & $<1$ \\
\hline & Ardea intermedia & Yellow-billed egret & 40 & 1 & $<1$ \\
\hline & Bubulcus ibis & Cattle egret & 50 & 8 & $<1$ \\
\hline & Nycticorax nycticorax & Black-crowned nightheron & 5 & $<1$ & $<1$ \\
\hline & Ixobrychus minutus & Little bittern & 40 & 1 & $<1$ \\
\hline Scopidae & Scopus umbretta & Hamerkop & 10 & $<1$ & $<1$ \\
\hline \multirow[t]{2}{*}{ Threskiornithidae } & Threskiornis aethiopicus & African sacred ibis & 25 & 1 & $<1$ \\
\hline & Bostrychia hagedash & Hadeda ibis & 45 & 4 & $<1$ \\
\hline Motacillidae & Motacilla capensis & Cape wagtail & 95 & 5 & $<1$ \\
\hline
\end{tabular}

Note: Species names follow Hockey et al. (2005). Freq. indicates the percentage of times a species was recorded in all surveys; Avg. is the average abundance of species across all 20 surveys; $\%$ is the percentage representation of a species in the community based on average abundance across all 20 surveys.

Freq., frequent; Avg., average.

artificial, and resultant reductions in water levels throughout the lakes system is a common occurrence (Figure 3). Postbreaching reduction in water level occurred just prior to the first disease outbreak (07 December 2014). The following three mechanical breachings during the disease period had a relatively minor effect on water levels. Subsequent natural breaching on 30 August 2015 and mechanical breaching on 03 September 2016 resulted in larger and longer duration reductions in water levels. Post-breaching reductions in water levels just prior to and during the outbreak period are, however, not atypical for these waterbodies with, as an illustration, 19 breachings in the prior 13 years resulting in either comparable or larger and longer duration reductions in lake water levels (Figure 3).

Seasonal variations in water temperature were similar in all waterbodies (Figure 4a), with the highest temperature occurring in January (summer) and the lowest in July (midwinter). Variability and extremes in water temperature during the disease outbreak did not notably differ from that recorded in earlier years (Figure 4a).

Salinity in the Wilderness Lakes fluctuated temporally depending on the timing and volume of inflows of fresh river 
TABLE 4: The number of dead fish located in Rondevlei, Langvlei and Eilandvlei in the three different botulism outbreak periods encompassing January-June 2015, November 2015 - August 2016 and January-May 2017.

\begin{tabular}{|c|c|c|c|c|c|c|c|c|c|c|c|c|c|c|}
\hline \multirow[t]{2}{*}{ Orign } & \multirow[t]{2}{*}{ Species } & \multirow[t]{2}{*}{ Common name } & \multicolumn{4}{|c|}{ Rondevlei } & \multicolumn{4}{|c|}{ Langvlei } & \multicolumn{4}{|c|}{ Eilandvlei } \\
\hline & & & 2015 & 2016 & 2017 & Total & 2015 & 2016 & 2017 & Total & 2015 & 2016 & 2017 & Total \\
\hline \multirow[t]{2}{*}{ Alien } & Cyprinus carpio & Common carp & 0 & 0 & 0 & 0 & 32 & 16 & 27 & 75 & 5 & 9 & 0 & 14 \\
\hline & Oreochromis mossambicus & Mozambique tilapia & 0 & 0 & 0 & 0 & 7 & 1 & 0 & 8 & 0 & 0 & 0 & 0 \\
\hline \multirow[t]{6}{*}{ Indigenous } & Pomadasys commersonnii & Spotted grunter & 0 & 0 & 1 & 1 & 0 & 1 & 0 & 1 & 6 & 4 & 0 & 10 \\
\hline & Lithognanis lithoglanis & White steenbras & 0 & 2 & 0 & 2 & 0 & 1 & 0 & 1 & 0 & 3 & 0 & 3 \\
\hline & Mugil cephalis & Flathead mullet & 0 & 1 & 1 & 2 & 1 & 0 & 2 & 3 & 0 & 0 & 0 & 0 \\
\hline & Rhabdosargus holubi & Cape stumpnose & 1 & 0 & 0 & 1 & 0 & 0 & 0 & 0 & 0 & 0 & 0 & 0 \\
\hline & Monodactylus falciformis & Oval moonie & 0 & 0 & 0 & 0 & 1 & 0 & 0 & 1 & 0 & 0 & 0 & 0 \\
\hline & Lichia amia & Leervis & 0 & 0 & 0 & 0 & 0 & 0 & 0 & 0 & 0 & 2 & 0 & 2 \\
\hline Total & - & - & 1 & 3 & 2 & 6 & 41 & 19 & 29 & 89 & 11 & 18 & 0 & 29 \\
\hline
\end{tabular}

Note: Species names follow Whitfield (2019) and Skelton (2001).

Survey dates for the three locations were as follows: Rondevlei 2015: January-June 2015, Rondevlei 2016: November 2015 - August 2016 and Rondevlei 2017 : January-May 2017; Langvlei 2015 February-June 2015, Langvlei 2016: November 2015-June 2016 and Langvlei 2017: January-May 2017; Eilandvlei 2015: February-May 2015, Eilandvlei 2016: January-June 2016 and Eilandvlei 2017: January-May 2017.

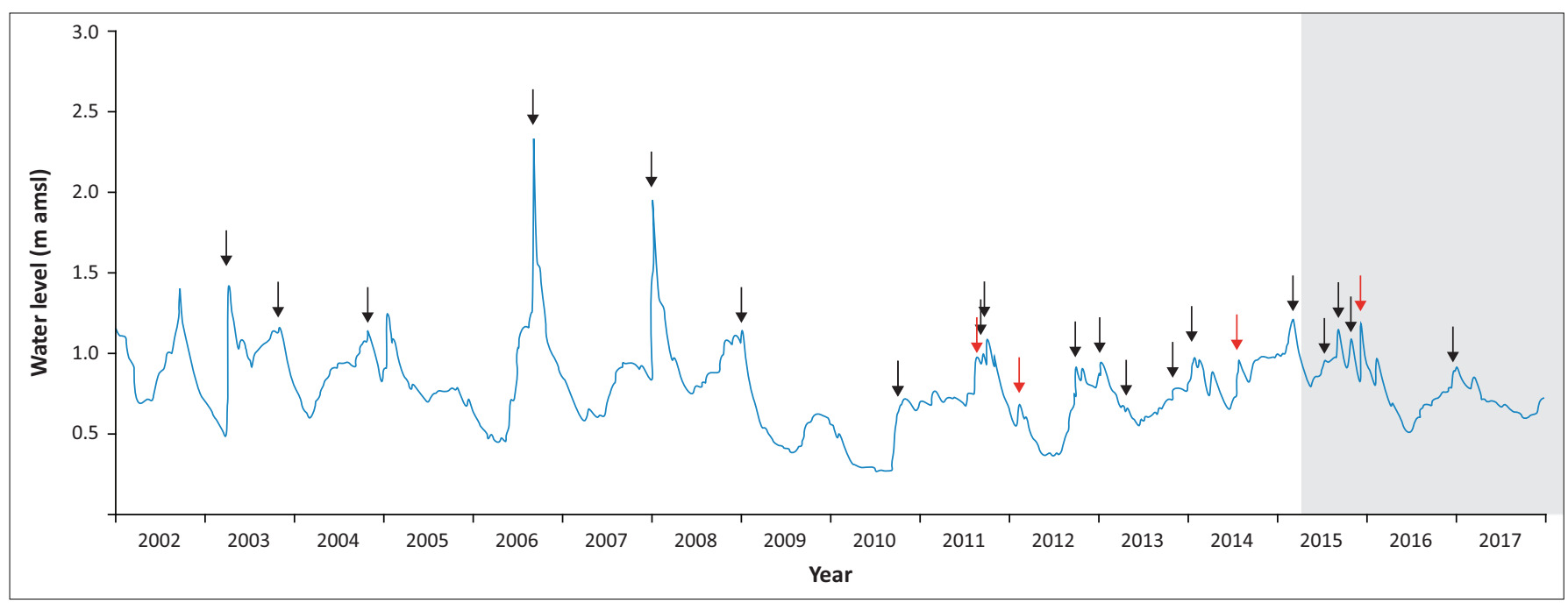

FIGURE 3: Water level relative to sea level in Rondevlei from 2002 to 2017 . Arrows indicate times of breaching of the Touw Estuary mouth (black $=$ artificial breaching, red = natural breaching). Shaded area indicates the period when botulism-related deaths of waterbirds were recorded in the Wilderness Lakes.

water, saline marine waters and brackish groundwater, the state of the estuary mouth, the movement of water between lakes, and the timing and rate of water loss through evaporation, evapotranspiration and groundwater movement. All of the lakes became progressively less saline until early 2008 after which an extended low rainfall period resulted in increases in salinity, which stabilised mostly within the range of 5-10 between 2010 and 2017 (Figure 4b). Rondevlei is typically more saline than both Langvlei and Eilandvlei. Variability in salinity did not differ substantially in the period of disease outbreak (2015-2017) from the prior 5 years, and from 2010 onwards never fell below 5, which Rocke and Friend (1999) describe as more conducive for avian botulism outbreaks.

Dissolved oxygen in the lakes is naturally variable, with higher oxygen levels frequently occurring in the cooler winter months, and relatively lower dissolved oxygen levels occurring during the warmer summer months. This distinctive variability also occurred during the period of disease outbreak, and with both upper and lower dissolved oxygen levels not being atypical, or exceeding those recorded in the 11 years prior to the disease outbreak (Figure 4c).
The $\mathrm{pH}$ within the lakes mostly fluctuated within the range of 7-9 (Figure 4d), and was rarely lower than 6.5, below which botulism outbreaks do not occur (Rocke \& Friend 1999), except for short periods ( $<3$ months) in Eilandvlei following high freshwater inflows. Variability in $\mathrm{pH}$ mostly within the range conducive for botulism outbreaks did not differ between the period of disease outbreak and earlier years (Figure $4 \mathrm{~d}$ ).

Little to no algae were detected in water samples collected during the height of the first disease outbreak. The dominant diatom was Pleurosigma salinarum, an indicator of brackish water. Toxic cyanobacteria detected were Oscillatoria tenue and Oscillatoria princeps. These were only observed in samples from the Rondevlei-Langvlei channel, and abundances were too low to cause toxicity in the water (P. Oberholster pers. comm., 09 November 2015).

Temporal variation in the biomass of submerged aquatic plants was substantial in all three estuarine lakes (Figure $5 \mathrm{a}-\mathrm{c}$ ). Declines in the standing biomass of aquatic plants, and consequently potential increases in decaying organic plant matter, occurred prior to the initial 2015 avian disease outbreak in both Rondevlei (Figure 5a), and to a lesser 

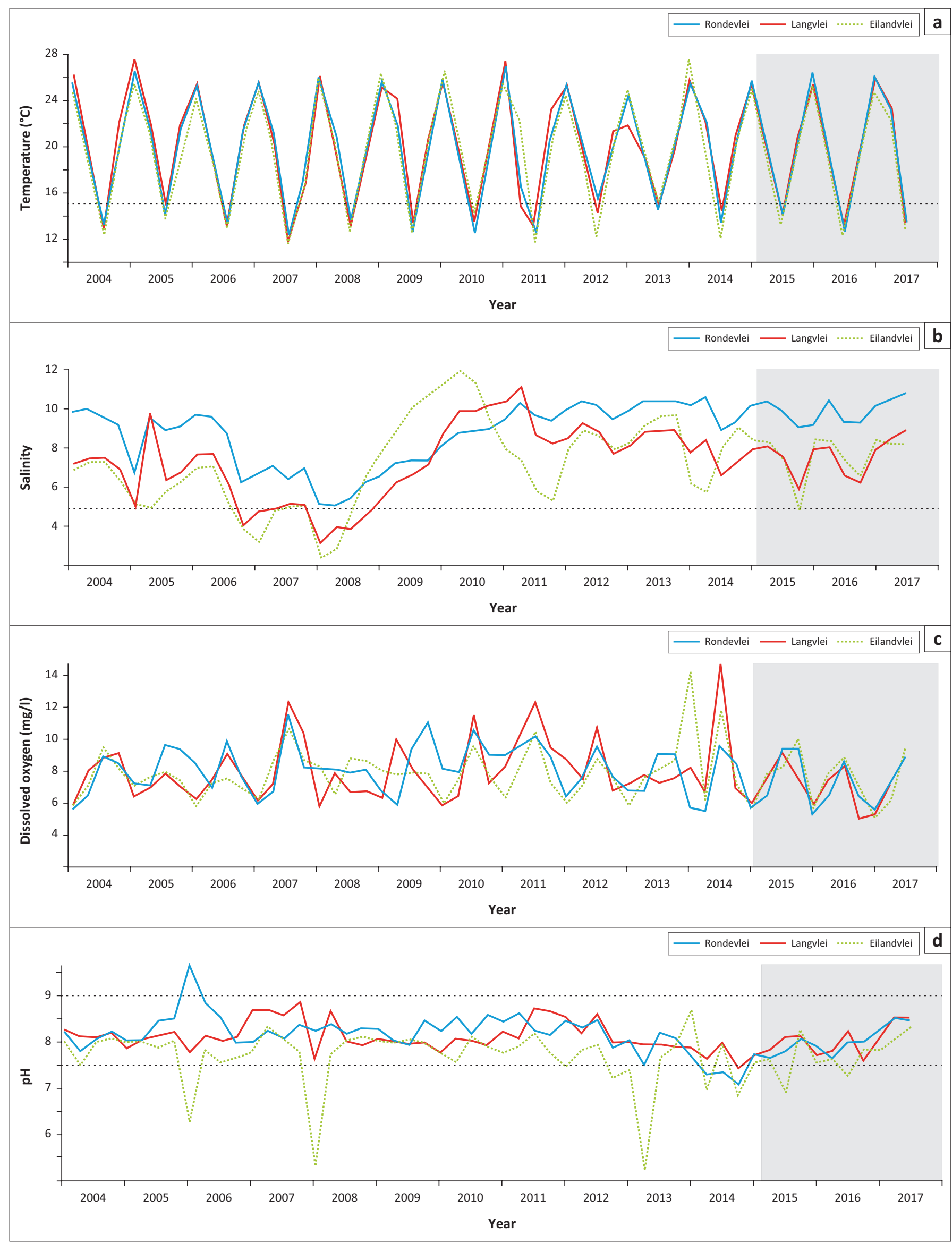

FIGURE 4: Time series plots of (a) mean water temperature, (b) salinity, (c) dissolved oxygen and (d) pH collected in January, April, July and October of each year from 2004 to 2017 in Rondevlei (blue), Langvlei (red) and Eilandvlei (green). Horizontal dotted lines indicate environmental limits conducive for botulism occurrence for temperature $\left(>15^{\circ} \mathrm{C}\right.$ ), salinity $(<5)$ and $\mathrm{pH}(7.5<\mathrm{pH}<9.0)$ (Rocke \& Friend 1999). The shaded area indicates the period when botulism-related deaths of waterbirds were recorded in the Wilderness Lakes. 

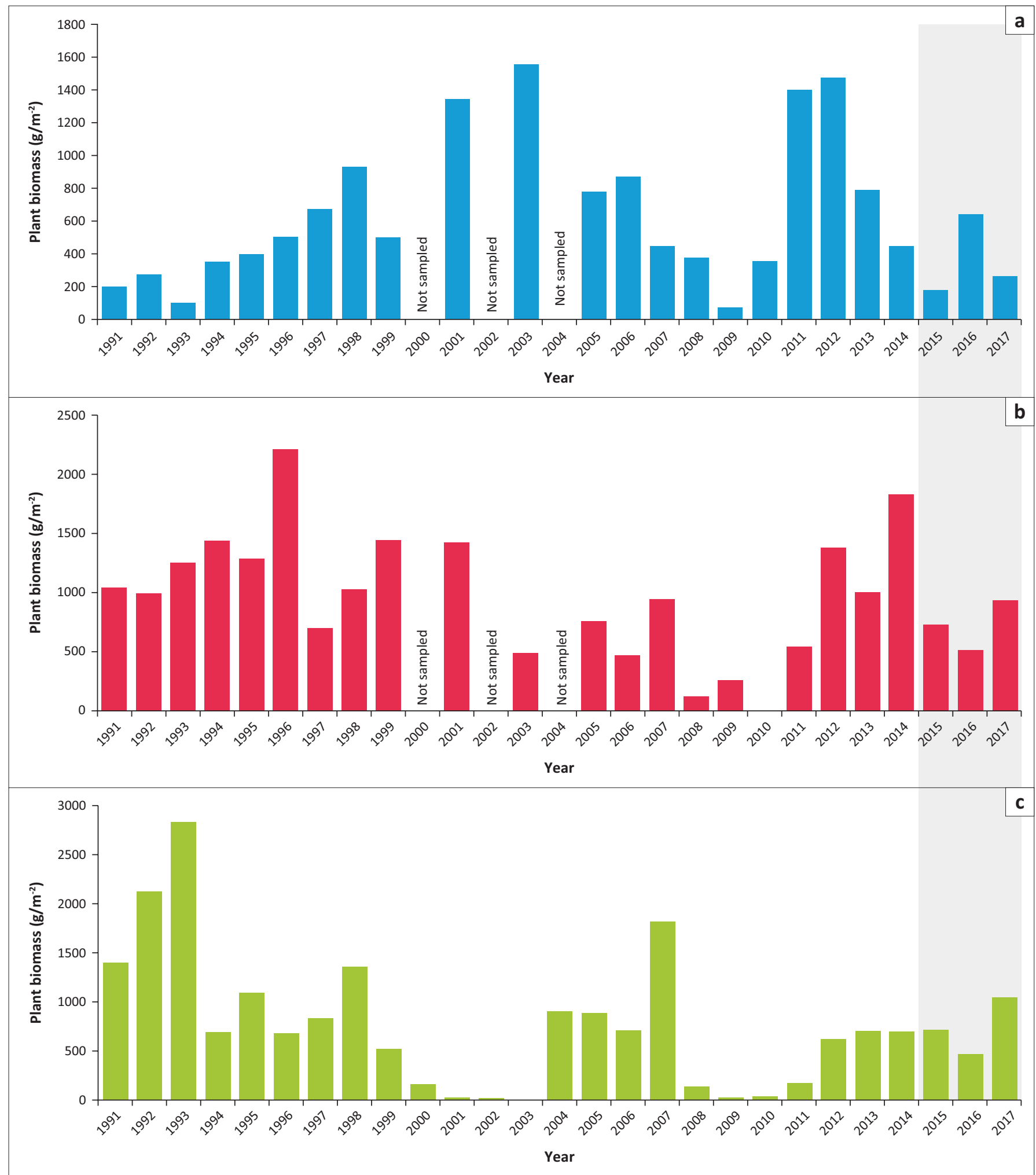

FIGURE 5: The biomass of submerged plants determined annually in the period of maximum biomass (May-June) in (a) Rondevlei, (b) Langvlei and (c) Eilandvlei from 1991 to 2017 .

extent in Langvlei (Figure 5b). No comparable substantial declines were recorded in Eilandvlei (Figure $5 c$ ). The variability in submerged aquatic plant biomass recorded in Rondevlei and Langvlei since 2015 was, however, not atypical, with periodic substantial declines having occurred in all waterbodies in the years prior to the avian disease outbreak, notably in 2000-2003 in Eilandvlei and in 2008-2010 in all three lakes.

\section{Discussion}

A diagnosis of avian botulism is frequently based on a combination of symptoms displayed by sick birds, and the absence of specific post-mortal findings (Rocke \& Bollinger 2007). Patterns of mortality and behaviour of affected, and in extremis, waterbirds on the Wilderness Lakes were classic 
for avian botulism, as described by Rocke and Friend (1999) and Rocke and Bollinger (2007), which along with the absence of any obvious lesions in dead birds, and the absence of toxic algae, indicate that a diagnosis of avian botulism is reasonable. The absence of a positive mouse bioassay does not invalidate this diagnosis, as although it is still considered the most sensitive test for all C. botulinum types (Rocke \& Bollinger 2007), false negatives may occur (Rocke et al. 2004; Thomas 1991).

The number of observed dead and sick waterbirds is substantial, comprising approximately $20 \%$ of the average number of all susceptible waterbird species on the affected lakes. This is quite probably an underestimation, as assessments of total waterbird mortality based only on carcass retrieval can result in the underestimation of actual mortality by between three (Cliplef \& Wobeser 1993) and 10 times (Stutzenbaker et al. 1986 cited in Rocke \& Bollinger 2007). The effect of the disease on dabbling ducks in general is of concern, and particularly Cape shoveler, a near-endemic species to Southern Africa (Hockey, Dean \& Ryan 2005), the recorded deaths of which constitute approximately $75 \%$ of their average population on the affected lakes.

One obvious question relevant to the management of the Wilderness Lakes is why has there been an outbreak of botulism here and now? Clostridium botulinum spores occur naturally in most wetland sediments where they can persist for decades and can be found in the body tissues of most wetland biota, including healthy birds (Rocke \& Friend 1999). The mechanisms triggering spore germination and bacterium growth leading to botulism outbreaks remain poorly understood (Espelund \& Klaveness 2014), although several predisposing environmental factors have been proposed. The prevalence of higher environmental botulism has been linked to falling water levels, higher summer surface-water temperatures, decaying organic material, water $\mathrm{pH}$ of between 7.5 and 9.0, water salinity of below 5, and low dissolved oxygen levels (Perez-Fuentetaja et al. 2006; Rocke, Euliss \& Samuel 1999; Rocke \& Samuel 1999). Therefore, many of the environmental conditions prevalent at the time of the outbreak were not conducive to botulism outbreaks, and the lakes were not undergoing any atypical fluctuations compared to historical data. Water level fluctuations, temperature, salinity, dissolved oxygen and level of decaying senescent aquatic plants were all very consistent with years when there were no disease outbreaks. However, the one environmental factor that does differ from the years prior to the botulism outbreaks is the introduction and proliferation of alien common carp (Olds et al. 2011), the most abundant fish species recorded in botulism concurrent mortalities in the Wilderness Lakes. Common carp, a primarily freshwater species, was first observed in Eilandvlei in 2005 (personal observation made by I.A. Russell), when water salinity was relatively low, although the exact date and place of introduction is unknown. They now occur in all lakes in the Wilderness system. The role that common carp play in triggering botulism outbreaks by scavenging in the benthic layer where $C$. botulinum may have proliferated in vegetation and insects, mobilising organic-rich, potentially anoxic sediments during feeding (Skelton 2001) or perpetuating outbreaks with the carcasses of large individuals providing a decaying organic source, remains speculative, although worthy of investigation.

All birds, except vultures (Cohen et al. 1969), are thought to be susceptible to ingested avian botulism neurotoxin, although interspecific differences in susceptibility may occur (Bollinger 2011), with diet and feeding patterns playing a role in their exposure to the toxin. In the Wilderness Lakes, the Cape shoveler, a dabbling duck (Brickell 1988), was found to be highly susceptible, whereas many species, particularly most piscivorous species and waders were unaffected. This is consistent with the findings of Rocke (2006) that dabbling ducks are amongst the waterbirds most susceptible to type C/D botulism, with diving ducks seemingly less affected. The particularly high mortality of Cape shoveler also mirrors the observation that mallards and shovelers are the species at greatest risk from type $C$ (Rocke \& Bollinger 2007). A high mortality amongst redknobbed coot in the Wilderness Lakes is similar to the findings of Anza et al. (2016) who found coot to be highly vulnerable to type C/D botulism, with the source of the toxins thought to be invertebrates on plants and carcasses.

Both similarities and differences occur in the species affected in this and earlier reported botulism outbreaks amongst waterbirds in South Africa. Whereas Van Heerden (1972) similarly reported mostly duck species to be affected in a botulism outbreak in a pan in central South Africa (Welkom, South Africa), along with red-knobbed coot, grey-headed gull (Larus cirrocephalus), greater flamingo, blacksmith lapwing and black-winged stilt (Himantopus himantopus), observed mortalities differed from that in the Wilderness Lakes in that both common moorhen and waders in the family Scolopacidae were also affected. Similarly, Blaker (1967) also recorded the mortality of several small waders at the Strandfontein sewage works (Cape Town, South Africa). The botulism outbreak recorded by Blaker (1967), similar to that in the Wilderness Lakes, also affected several duck species, although it differed in that while the Cape shoveler was highly susceptible in the Wilderness Lakes, only one individual ( $1 \%$ of the population) of this species was reported by Blaker (1967), with Cape teal (Anas capensis), another dabbling duck (Brickell 1988), being the most affected species. The susceptibility of greater flamingo also appears to differ between outbreaks, with a high mortality reported on Kamfers Dam (Kimberley, South Africa) (Ramollo 2016), whereas few deaths of this species occurred on Wilderness Lakes, despite being abundant in the summer of 2016 ( \pm 450 individuals). Similarly, no deaths of greater flamingo were recorded by Van Heerden (1972) despite being common during that botulism outbreak. Greater flamingo in Europe are considered by Anza et al. (2016) to be less susceptible to type C/D botulism. Differences in the species affected between outbreaks suggest variances in the mode of disease transmission. 
The transfer of toxins to waterbirds is thought to occur mainly through zooplankton or invertebrate food items that have assimilated toxins (Rocke \& Friend 1999). Fish may also act as vectors for botulinum type E toxin, with affected fish being consumed by piscivorous or scavenging birds (Getchell \& Bowser 2006), or their carcasses providing a protein source for bacterial growth and consequently toxin production (Eklund et al. 1984), thereby affecting birds via the carcassmaggot cycle. The presence of dead fish during botulism outbreaks in the Wilderness Lakes suggests that botulinum type E toxin may be implicated. However, rather unusually, most piscivorous birds, including the abundant reed cormorant, African darter (Anhinga rufa) and black-necked grebe (Podiceps nigricollis), as well as herons, terns and most kingfishers, were unaffected in this instance. More remains to be learned about the origin, strain, drivers and transmission of the disease in the Wilderness Lakes, and the cause and ecology of the disease remains speculative.

\section{Management implications}

The long-term effect of repeated outbreaks of avian botulism on the abundance of susceptible waterbird species in the Wilderness Lakes is of concern. The previous regular high abundance of duck species, particularly yellow-billed duck and Cape shoveler, was the initial reason for the Wilderness Lakes being declared a Ramsar site. The effect of ongoing high disease-related mortalities may, in part, prevent these wetlands from continuing to regularly support globally significant populations of some waterbird species. The containment of the disease must be attempted by the regular collection and removal of dead birds and fish during the outbreak periods of November-June, and the disposal of carcasses off-site. Further testing of affected individuals should be undertaken and monitoring of environmental variables and affected individuals continued, to improve the understanding of the drivers and progression of the disease.

Serotyping C. botulinum in the soil of various important wetlands in Southern Africa will assist in detecting hotspots for potential outbreaks. The regular monitoring of environmental conditions will increase predictive capability, informing both proactive management of these important wetland and lake environments, to prevent outbreaks and to allow for early detection if an outbreak occurs, and therefore enable rapid response to minimise environmental contamination.

\section{Acknowledgements}

The authors wish to thank Paul Oberholster for identification of algae species, Emily Mitchell for assistance with the histopathology and members of the Garden Route National Park ranger team, notably Davie Antas, Nelson Tyhali, Petrus Mitchell, Donavan McKeith, Charles April and Jonathan Britton, for undertaking the unpopular task of carcass location and disposal. The authors also wish to thank two anonymous reviewers for their helpful comments on an earlier draft of the article.

\section{Competing interests}

The authors declare that they have no financial or personal relationships that may have inappropriately influenced them in writing this article.

\section{Authors' contributions}

R.M.R. initiated and oversaw surveys of dead birds in 2015. $\mathrm{He}$ also arranged a visit by state veterinarians. I.A.R. participated in dead bird surveys from 2015 to 2017, undertook water quality and aquatic plant surveys and maintained databases on water heights and estuary breaching. He undertook the data analysis and wrote the article. D.G. arranged for botulism testing. D.Z. collected tissue samples and arranged for some histopathological examinations. R.M.R., D.G. and D.Z. proofread and contributed to the article.

\section{Funding information}

The South African National Parks (SANParks) funded this research. The State Veterinarian Office of the Western Cape Government undertook infield inspections, postmortem and histopathological examinations, and provided advice and diagnoses. The Wildlife Pathology Research of the National Zoological Gardens undertook post-mortem and histopathological examinations. The Agricultural Research Council-Onderstepoort Veterinary Institute undertook mouse bioassays, bacterial cultures and histopathological examinations. The Stellenbosch Office of the Council for Scientific and Industrial Research (CSIR) identified algae species.

\section{Data availability statement}

Data are available from the first author upon request.

\section{Disclaimer}

The views and opinions expressed in this article are those of the authors and not an official position of SANParks or any institute or organisation that undertook tests in support of this study.

\section{References}

Adamson, P.T., 1975, Extension of monthly runoff records in the catchments of the Wit Els, Diep and Karatara rivers - Wilderness - Cape Province, Department of Water Affairs, Pretoria.

American Public Health Association, American Water Works Association \& Water Pollution Control Federation, 1992, Standard methods for the examination of water and wastewater, 18th edn., American Public Health Association, American Water Works Association \& Water Pollution Control Federation, Washington, DC.

Anza, I., Skarin, H., Vidal, D., Lindberg, A., Båverud, V. \& Mateo, R., 2014, 'The same clade of Clostridium botulinum strains is causing avian botulism in southern and northern Europe', Anaerobe 26, 20-23. https://doi.org/10.1016/j.anaerobe. 2014.01.002

Anza, I., Vidal, D., Feliu, J., Crespo, E. \& Mateoa, R., 2016, 'Differences in the vulnerability of waterbird species to botulism outbreaks in Mediterranean wetlands: An assessment of ecological and physiological factors', Applied and Environmental Microbiology 48(10), 3092-3099. https://doi.org/10.1128/AEM 00119-16

Blaker, D., 1967, 'An outbreak of botulinus poisoning among waterbirds', Ostrich 38(2), 144-147. https://doi.org/10.1080/00306525.1967.11783617

Bollinger, T.K., Evelsizer, D.D., Dufour, K.W., Soos, C., Clark, R.G., Wobeser, G. et al., 2011, Ecology and management of avian botulism on the Canadian prairies. Prairie Habitat, Joint Venture Science Committee. 
Boshoff, A.F., Palmer, N.G. \& Piper, S.E., 1991a, 'Spatial and temporal abundance patterns of waterbirds in the southern Cape Province. Part 1: Diving and surface predators', Ostrich 62(3-4), 156-177.

Boshoff, A.F., Palmer, N.G. \& Piper, S.E., 1991b, 'Spatial and temporal abundance patterns of waterbirds in the southern Cape Province. Part 2: Waterfowl', Ostrich 62(3-4), 178-196.

Boshoff, A.F., Palmer, N.G. \& Piper, S.E., 1991c, 'Spatial and temporal abundance patterns of waterbirds in the southern Cape Province. Part 3: Wading birds', Ostrich 62(3-4), 197-214.

Brickell, N., 1988, Ducks, geese and swans of Africa and its outlying islands, Frandsen Publishers, Fourways.

Cliplef, D.J. \& Wobeser, G., 1993, 'Observations on waterfowl carcasses during a botulism epizootic', Journal of Wildlife Diseases 29(1), 8-14. https://doi.org/ 10.7589/0090-3558-29.1.8

Cohen, G.M., Pates, A.L., Easton, D.M. \& Peterson, M.G., 1969, 'Vulture and rooster resistance to botulinus toxin', American Zoologist 9, 584

Collins, M.D. \& East, A.K., 1998, 'Phylogeny and taxonomy of the food-borne pathogen Clostridium botulinum and its neurotoxins', Journal of Applied Microbiology 84, 5-17. https://doi.org/10.1046/j.1365-2672.1997.00313.x

Cromie, R.L., Lee, R., Delahay, R.J., Newth, J.L., O’Brien, M.F., Fairlamb, H.A. et al., 2012, Ramsar wetland disease manual: Guidelines for assessment, monitoring
and management of animal disease in wetlands, Ramsar Technical Report No. 7, Ramsar Convention Secretariat, Gland.

Eklund, M.W., Poysky, F.T., Petersen, M.E., Peck, L.W. \& Brunson, W.D., 1984, 'Type E botulism in salmonids and conditions contributing to outbreaks', Aquaculture 41(4), 293-309. https://doi.org/10.1016/0044-8486(84)90198-4

Espelund, M. \& Klaveness, D., 2014, 'Botulism outbreaks in natural environments - an update', Frontiers in Microbiology 5, 1-7. https://doi.org/10.3389/fmicb.2014. 00287

Fijen, A.P.M. \& Kapp, J.F., 1995, Wilderness, Swartvlei and Groenvlei Lakes catchment water management strategy. Proposed water management strategy, objectives and goals, Department of Water Affairs and Forestry Report No. WQ K100/00/1395 Z/Z/Z, Pretoria.

Filmalter, E. \& O'Keeffe, J.H., 1997, Effects of land-use changes on the rivers of the Wilderness Lakes, Report to Department of Environment Affairs, Institute for Wilderness Lakes, Report to Department of Envi
Water Research, Rhodes University, Grahamstown.

Getchell, R.G. \& Bowser, P.R., 2006, 'Ecology of type E botulism within dreissenid mussel beds', Aquatic Invaders 17(2), 1-8.

Grubb, W.B., 1964, 'Avian botulism in Western Australia', The Australian Journal of Experimental Biology and Medical Science 42(1), 17-26. https://doi.org/10.1038/ icb.1964.2

Hall, C.M., Whitfield, A.K. \& Allanson, B.R., 1987, 'Recruitment, diversity and the influence of constrictions on the distribution of fishes in the Wilderness Lakes System, South Africa', South African Journal of Zoology 22(2), 163-169. https:// doi.org/10.1080/02541858.1987.11448038

Hockey, P.A.R., Dean, W.R.J. \& Ryan, P.G. (eds.), 2005, Roberts birds of Southern Africa, 7 th edn., The Trustees of the John Voelcker Bird Book Fund, Cape Town.

Howard-Williams, C. \& Liptrot, M.R.M., 1980, 'Submerged macrophyte communities in a brackish South African estuarine-lake system', Aquatic Botany 9, 101-116. https://doi.org/10.1016/0304-3770(80)90012-1

Howard-Williams, C. \& Longman, M., 1976, 'A quantitative sampler for submerged aquatic macrophytes', Journal of the Limnological Society of Southern Africa 2(1) 31-33. https://doi.org/10.1080/03779688.1976.9632918

Martinovich, D., Carter, M.E., Woodhouse, D.A. \& McCausland, I.P., 1972, 'An outbreak of botulism in wild waterfowl in New Zealand', New Zealand Veterinary Journal 20(5), 61-65. https://doi.org/10.1080/00480169.1972.34012

Olds, A.A., Smith, K.S., Weyl, O.L.F. \& Russell, I.A., 2011, 'Occurrence of alien invasive freshwater fishes in the Wilderness Lakes system, a wetland of international importance, Western Cape, South Africa', African Zoology 46(1), 179-184. https:// doi.org/10.1080/15627020.2011.11407491

Perez-Fuentetaja, A., Clapsad, M.D., Einhouse, D., Bowser, P.R., Getchell, R.G. \& Lee, W.T., 2006, 'Influence of limnological conditions on Clostridium botulinum type E presence in eastern Lake Erie sediments (Great Lakes, USA)', Hydrobiologia 563(1), 189-200. https://doi.org/10.1007/s10750-005-0011-1

Ramollo, P., 2016, 'Jewel of the Northern Cape is fading due to pollution', The Wate Wheel Jan/Feb 2016, 36-38.

Ramsar Convention Bureau, 2019, The list of wetlands of international importance, Ramsar Convention Bureau, Gland, Switzerland.

Robarts, R.D. \& Allanson, B.R., 1977, 'Meromixis in the lake-like upper reaches of a South African estuary', Archiv für Hydrobiologie 80(4), 531-540.
Rocke, T.E., 2006, 'The global importance of avian botulism', in G.C. Boere, C.A. Galbraith \& D.A. Stroud (eds.), Waterbirds around the world, pp. 422-426, The Stationery Office, Edinburgh.

Rocke, T.E. \& Bollinger, T.K., 2007, 'Avian botulism', in N.J. Thomas, D.B. Hunter \& C.T. Atkinson (eds.), Infectious diseases of wild birds, pp. 377-416, Blackwell Publishing, Ames, IA

Rocke, T.E. \& Friend, M., 1999, 'Avian botulism', in M. Friend \& J.D. Franson (eds.), Field manual of wildlife disease: General procedures and diseases of birds, pp. 271-281, USGS National Wildlife Health Center, Washington, DC.

Rocke, T.E. \& Samuel, M.D., 1999, 'Water and sediment characteristics associated with avian botulism outbreaks in wetlands', Journal of Wildlife Management 63(4), 1249-1260. https://doi.org/10.2307/3802842

Rocke, T.E., Euliss, N.H. \& Samuel, M.D., 1999, 'Environmental characteristics associated with the occurrence of avian botulism in wetlands of a northern California refuge', Journal of Wildlife Management 63(1), 358-368. https://doi. org $/ 10.2307 / 3802520$

Rocke, T.E., Nol, P., Pelliza, C. \& Sturm, K., 2004, 'Type C botulism in pelicans and other fish-eating birds at the Salton Sea', Studies in Avian Biology 27, 36-140.

Russell, I.A., 1996, 'Fish abundance in the Wilderness and Swartvlei lake systems: Changes relative to environmental factors', South African Journal of Zoology 31(1) 1-9. https://doi.org/10.1080/02541858.1996.11448389

Russell, I.A., Randall, R.M. \& Hanekom, N., 2014, 'Spatial and temporal patterns of waterbird assemblages in the Wilderness Lakes Complex, South Africa', Waterbirds 37(1), 1-18. https://doi.org/10.1675/063.037.0104

Skelton, P.H., 2001, A complete guide to the freshwater fishes of Southern Africa, Southern Book Publishers, Halfway House.

Smith, G.R., 1976, 'Botulism in waterfowl', Wildfowl 27, 129.

South African National Parks, 2012, Garden Route National Park: Park management plan appendices, pp. 135-150, South African National Parks, Pretoria.

Stutzenbaker, C.D., Brown, K. \& Lobpries, D., 1986, 'Special report: An assessment of the accuracy of documenting waterfowl die-offs in a Texas coastal marsh', in J.S Feierabend \& A.B. Russel (eds.), Lead poisoning in wild waterfowl, pp. 88-95, National Wildlife Federation, Washington, DC

Taylor, J.C., Harding, W.R. \& Archibald, C.G.M., 2007, An illustrated guide to some common diatom species from South Africa, WRC Report No. TT 282/07, Water Research Commission, Pretoria.

Thomas, R.J., 1991, 'Detection of Clostridium botulinum type C and D toxin by ELISA' Australian Veterinary Journal 68(3), 111-113. https://doi.org/10.1111/j.1751 0813.1991.tb00769.x

Truter, E., 1987, An aid to the identification of the dominant and commonly occurring genera of algae observed in some South African impoundments, Technical Report No. TR 135, South African Department of Water Affairs, Pretoria.

Van Heerden, J., 1972, 'Botulisme breek uit in Welkom', Bokmakierie 24(3), 60-61.

Van Vuuren, S., Taylor, J.C., Gerber, A. \& Van Ginkel, C., 2006, Easy identification of the most common freshwater algae, North-West University and Department of Water Affairs and Forestry, Pretoria.

Wehr, J.D. \& Sheath, R.G., 2003, Freshwater algae of North America: Ecology and classification, Academic Press, San Diego, CA.

Weisser, P.J. \& Howard-Williams, C., 1982, 'The vegetation of the Wilderness Lakes System and the macrophyte encroachment problem', Bontebok 2, 19-40.

Whitfield, A.K., 1984, 'The effects of prolonged aquatic macrophyte senescence on the biology of the dominant fish species in a Southern African coastal lake', Estuarine, Coastal and Shelf Science 18(3), 315-329. https://doi.org/10.1016/ 0272-7714(84)90074-X

Whitfield, A.K., 2019, Fishes of Southern African estuaries: From species to systems, Smithiana Monograph No. 4, South African Institute for Aquatic Biodiversity, Grahamstown.

Whitfield, A.K., Allanson, B.R. \& Heinecken, T.J.E., 1983, Estuaries of the Cape, Swartvlei (CMS 11), Report No. 22, Council for Industrial and Scientific Research, Stellenbosch.

Włodarczyk, R., Minias, P., Kukier, E., Grenda, T., Śmietanka, K. \& Janiszewski, T., 2014 'The first case of a major avian type C botulism outbreak in Poland', Avian Diseases 58(3), 488-490. https://doi.org/10.1637/10669-091913-Case.1

Wobeser, G.A., 1997, Diseases of wild waterfowl, Plenum Press, New York.

Woudstra, C., Skarin, H., Anniballi, F., Fenicia, L., Bano, L., Drigo, I. et al., 2012, 'Neurotoxin gene profiling of Clostridium botulinum types C and D native to different countries within Europe', Applied and Environmental Microbiology 78(9), 3120-3127. https://doi.org/10.1128/AEM.07568-11 